\title{
Developing an integrated approach to interpret New Testament use of the Old Testament
}

\author{
Authors: \\ Gregory Y. Phillips ${ }^{1}$ \\ Fika Janse van Rensburg \\ Herrie F. van Rooy ${ }^{1}$ \\ Affiliations: \\ ${ }^{1}$ Research Unit for Reformed \\ Theology, North-West \\ University, South Africa \\ Correspondence to: \\ Greg Phillips \\ Email: \\ gregcarolphillips@gmail.com \\ Postal address: \\ 9 Leopold Street, King \\ William's Town 5601, \\ South Africa \\ Dates: \\ Received: 25 Oct. 2010 \\ Accepted: 11 Mar. 2011 \\ Published: 16 Nov. 2012 \\ How to cite this article: \\ Phillips, G.Y., Janse van \\ Rensburg, F. \& Van Rooy, \\ H.F., 2012, 'Developing an \\ integrated approach to \\ interpret New Testament use \\ of the Old Testament', In die \\ Skriflig/In Luce Verbi 46(2), \\ Art. \#50, 10 pages. http:// \\ dx.doi.org/10.4102/ids. \\ v46i2.50
}

The aim of this article is to develop a specific approach to interpreting New Testament use of the Old Testament. The approach has integrated the most useful insights of studies in both Second Temple Judaism and present day literary theory in order to reach most consistently and effectively a valid explanation of the biblical data. In the process, several important hermeneutical issues have been addressed. The focus of New Testament use of the Old Testament in the person and redemptive work of Jesus should always be the goal of Christian interpretation. Whilst old and new texts mutually interpret one another, it has been argued that there has been no ultimate ambiguity about the author's intended, singular meaning or distortion of the original meaning of the old text. It is important to be aware that all readers come to a text with preconceived worldviews that are inevitably a mixture of biblical and unbiblical perspectives. However, this does not prevent a reader from attaining a valid understanding that adequately overlaps with the most probable meaning of the text as intended by the author. This most probable meaning is determined by the explanation that logically makes the most coherent and natural sense of most biblical data. The methodological procedure proposed has taken the grammatical-historical method as the normative starting point of exegesis. It has then proceeded to imitate the New Testament in consideration of the broader canonical context, before considering explanations derived from the Second Temple literature or present day literary theory.

Die ontwerp van 'n geïntegreerde benadering om Nuwe-Testamentiese gebruik van die $\mathrm{Ou}$ Testament te verstaan. Die bedoeling met hierdie artikel is om ' $n$ benadering te ontwerp om die Nuwe-Testamentiese gebruik van die Ou Testament te verstaan. Dié benadering moet die mees bruikbare insigte van die navorsing oor die Tweede Tempelperiode en die hedendaagse literêre teorie integreer, met die oog daarop om op die mees konstante en effektiewe wyse 'n geldige verklaring van die Bybelse data te gee. In hierdie proses word etlike hermeneutiese vraagstukke onder die loep geneem. Aangesien die fokus van die Nuwe-Testamentiese gebruik van die Ou Testament die persoon en verlossingswerk van Jesus is, is dit nodig dat hierdie fokus by die Christen se verstaan ook teenwoordig is. Dit is so dat ouer en nuwer tekste mekaar interpreteer; dit hou egter nie in dat daar dubbelsinnigheid is oor die outeur se bedoelde enkele betekenis, of 'n skeeftrekking van die oorspronklike betekenis van die ouer teks nie. 'n Leser kom noodwendig na die teks met 'n spesifieke wêreldbeskouing, wat 'n mengsel is van Bybelse en onbybelse perspektiewe. Dit verhoed die leser egter nie om by 'n geldige verstaan van die teks uit te kom wat voldoende oorvleuel met die mees waarskynlike betekenis van die teks soos wat die outeur dit bedoel het en wat logieserwys die meeste van die bybelse data goed en organies verreken nie. Die voorgestelde benadering neem die grammaties-historiese metode as die normatiewe beginpunt vir eksegese, en volg dan die Nuwe Testament self na deur die breër kanoniese konteks te verreken. Eers dan word die literatuur van die Tweede Tempelperiode asook die literêre teorie van die huidige tyd verreken.

\section{Introduction}

From the very beginning, the apostles proclaimed the saving work of God in Christ as a fulfilment of what was written in the Scriptures of Israel ${ }^{1}$ (Hays \& Green 1995:222; Moyise 2001:1). Furthermore, the New Testament writers repeatedly expressed their concern for correctly handling the Scriptures (e.g. Lk 24:44-47; 1 Cor 15:3-4; 2 Pt 1:20-21; Heb 1:1), ${ }^{2}$ which means that not only the content but also the methods of their interpretations have important implications for Christians. As a result, many scholars have acknowledged the importance for Christian hermeneutics of the Old

1.See for example, Luke 24:44-47; 1 Corinthians 15:3-4; 2 Peter 1:20-21; Heb 1:1.

2.See for example, Acts 17:2; 18:24-28; 1 Timothy 1:6-10; 2 Timothy 2:15. 
Testament in the New Testement (e.g. Lk 24:44-47; 1 Cor 15:34; 2 Pt 1:20-21; Heb 1:1). ${ }^{3}$

Two broad interpretive approaches to the Old Testament in the New Testement may be distinguished:

- Some scholars focus on understanding Second Temple exegetical practices and then compare the way New Testament writers interpret the Old Testament with the interpretive conventions of the day (Hays \& Green 1995:229). ${ }^{4}$

- Other scholars take present day literary-critical approaches such as intertextuality and reader-response theory as their starting point and apply these to the use of the Old Testament by New Testament writers (Hays \& Green 1995:230). ${ }^{5}$

Both these approaches have their merits and are not mutually exclusive (Hays \& Green 1995:230). Thus, the aim of this article is to clarify the most helpful insights of each approach and then combine these in a complementary manner into a specific integrated approach that is the most effective and remains valid within the Reformed tradition. ${ }^{6}$ In addition, several important hermeneutical issues will be addressed because the New Testament use of the Old Testament is seldom explainable purely in terms of grammatical-historical exegesis.

To fulfil these goals we will analyse the most important and most recent literature relevant to New Testament use of the Old Testament in order to:

- Clarify the Scriptural sources of New Testament use of the Old Testament.

- Clarify the most useful insights of studies in Second Temple Judaism for understanding the New Testament use of the Old Testament.

- Clarify the most useful insights of some aspects of present day literary theory for understanding the New Testament use of the Old Testament.

- Clarify some further hermeneutical issues of New Testament use of the Old Testament.

- Develop a specific approach which takes into account the above insights and most consistently and effectively allows one to reach a valid explanation of the biblical data of New Testament use of the Old Testament.

\section{Scriptural sources of New Testament use of the Old Testament}

Any study concerning New Testament use of the Old Testament should take into account the following considerations:

3.See for example, Lindars (1976/1977:60); Beale (1989:94); Snodgrass (1994:29); Evans (2004:130); Bock (2006:255) and Kaiser (2007:96).

4.See for example, Longenecker (1975, 1987:5-6), Ellis (1993) and Enns (2003): 'In order to understand how the Old Testament functions in the New, we must immerse ourselves in the writings of the time' (Moyise 2001:7).

5.See for example, Hays (1989) and Moyise (2008).

6.Validity will be determined on the basis of consistency with a Reformed view on the inspiration, authority and inerrancy of Scripture (cf. Grudem 1994:47-138).
- In 1st-century Palestine the Hebrew, Greek and Aramaic texts were available in a number of versions and were not yet standardised (Moyise 2001:16-17; Longenecker 1975:64-65). ${ }^{7}$

- The Septuagint was the primary source of the Scriptures for the Christian Church yet it reflects a greater number of important variants than all the other translations put together (Tov 2001:142). As a result, New Testament scholars ought to be cautious in making statements about how a New Testament quotation differs from the Septuagint (Tov 2001:138-141; VanderKam \& Flint 2002:96-99; Moyise 2000:22, 2001:16).

- In the actual events described in the New Testament, the Old Testament was most likely cited in Aramaic, the everyday language of Palestine (Bock 2006:257). However, the Targums available today are relatively late manuscripts (Moyise 2001:17; Tov 2001:149-151) and therefore should only be used to give insight into the probable contemporary understanding of certain Old Testament passages.

- In addition to the conventional sources of Scripture, early Christians may have selected and collected together important Old Testament passages. The evidence for such testimonia consists in the fact that there is sometimes agreement in the combination of Scripture references from one New Testament writer to the next (Ellis 1996:50). ${ }^{8}$ At times, the similarity may go as far as agreement in wording which is unique by comparison with the wording of the Hebrew, Greek or Aramaic Scriptures (Snodgrass 1994:44-45; Moyise 2001:11-12 \& 17-18). ${ }^{9}$

Thus, it is recognised that New Testament writers were able 'to select from amongst various available text forms the reading most suitable for the purpose at hand' (Hays \& Green 1995:225). In addition, New Testament writers may at times have relied on memory which would account for some of the differences between quotations and the various known sources. At other times the New Testament writers may have altered the text form for semantic or interpretive purposes (Mickelsen 1963:255; Moyise 2001:18).

\section{Second Temple and Dead Sea Scrolls studies}

\section{An appraisal of relevance for studies on New Testament use of the Old Testament}

In scholarship, there is always the danger of turning too quickly to extra-biblical evidence in order to explain the message and interpretive methods of the New Testament (Kaiser 2007:97). However, it is equally dangerous to ignore the Second Temple interpretive environment altogether. An awareness of the literature, presuppositions and methods of the 1st century is essential.

\footnotetext{
7.See also Tov (2001:32-35, 116-117, 134-148) and VanderKam and Flint (2002:90, $96,110)$.

8.See for example, 1 Peter 2:6-10 and Romans 9:25-33.

9.See further Dodd (1952:110, 126-127), Longenecker (1975:89-92), Beale (1989:90) and Marshall (1994:196)
} 


\section{Second Temple Jewish literature}

Besides the various versions of Scripture, there are several main collections of Jewish literature. ${ }^{10}$ These are discussed below.

Jewish apocalyptic literature: The Jewish apocalyptic literature originates from the first two centuries BC and AD. It consists of interpretive retellings or extensions of biblical material (Helyer 2002:112-113, 119-124; cf. Longenecker 1975:26). The authors of the pseudepigraphic literature felt free to creatively rework both Israel's history and the biblical texts in order to convey new meaning using the traditional writings (Marcos 2006:321). There are places where the New Testament writers make reference to portions of the Jewish apocalyptic literature, ${ }^{11}$ but these are insufficient to prove that Jewish traditions had a significant impact on New Testament understanding of Old Testament events. Scholars have different views on whether or not these interpretive retellings transmitted in the New Testament should be taken as historical fact or mere legend (Helyer 2002:129-133). ${ }^{12}$ In our view, the inspiration and inerrancy of Scripture dictates that the New Testament writers only pass on what is historically true.

Rabbinic literature: Rabbinic or Talmudic literature represents the variety of traditional Pharisaic material (Longenecker 1975:23-25; Evans 2004:132). ${ }^{13}$ However, because the earliest Rabbinic literature post-dates the biblical era, ${ }^{14}$ it provides only probable but not certain evidence of the approaches and interpretive attitudes prevalent during the 1st-century AD (Enns 2003:273-274).

The Dead Sea Scrolls: The discovery of the Dead Sea Scrolls ${ }^{15}$ from 1947 to 1956 has made available a vast array of texts ${ }^{16}$ dating from about 200 to $50 \mathrm{BC}$. These texts provide much information about contemporary Jewish society and most importantly, fragments of over two hundred scrolls of the Hebrew Scriptures together with interpretations (VanderKam \& Flint 2002:321-345; Tov 2001:103). The Qumran texts have been carefully categorised, providing a helpful overview of the state of the variety of the biblical text during the Second Temple period. At the same time, this has

10.See VanderKam (2001) and Helyer (2002) for excellent recent treatments of this subject.

11.Enns (2003:272-273) lists and explains seven examples of Second Temple traditions that are commonly accepted by scholars as used in the New Testament (Gal 3:19; Acts 7:53; Heb 2:2; 2 Tim 3:8; 2 Pet 2:5; Jude 9; Jude 14-15; Acts 7:22 and 1 Cor 10:4). Moyise (2001:130-131) adds 2 Peter 2:4 and Jude 6 (angels had intercourse with women to produce giants).

12.See Enns (2003:270-273) and Beale (2006:31-34).

13.See Neusner (2004) for a comprehensive treatment.

14.The earliest Rabbinic Midrash compilations (c. AD 200-300) are commonly referred to as Tannaite or Halakhic Midrashim (e.g., Mekhilta attributed to R. Ishmael for Exodus, Sifra on Leviticus, Sifré to Numbers, Sifré to Deuteronomy). Another type of Rabbinic Midrash is characteristic of the approximate period AD 450-500 (e.g. Leviticus Rabbah, Pesiqta deRab Kahana and parts of Genesis Rabbah). The latest type of Rabbinic Midrash was produced about AD 500-600 (e.g., Song of Songs Rabbah, and to a lesser degree, Lamentations Rabbah, Ruth Rabbah, and Esther Rabbah) (Neusner 2004:15-16, 20-29).

15. Recent publications in English on the Dead Sea Scrolls include Fitzmyer (2000) Schiffman, Tov and VanderKam (2000), Herbert and Tov (2002), VanderKam and Flint (2002), Collins and Evans (2006) and many more, especially in the Discoveries in the Judaean Desert series.

16. Fragments of approximately 900 scrolls (Tov 2001:101-102). strengthened confidence in the reliability of translations of the Hebrew, especially the Septuagint (Tov 2001:114-117). The hermeneutical presuppositions, methods and goals of the Qumran community are now well understood and provide important comparisons for the New Testament use of the Old Testament (Moyise 2001:9; VanderKam \& Flint 2002:239-254; 349-350).

\section{Presuppositions of Second Temple and New Testament interpretation}

Ancient interpretations of Scripture may sometimes appear arbitrary or ad hoc to the present day mind, but this was almost certainly not the case to the ancient interpreters themselves (Moyise 2001:4-5). Therefore, it is most important to understand the presuppositions, methods and goals of ancient Jewish and early Christian interpretation (Beale 1994b:9; Ellis 1993:199-219). It is evident in the New Testament that early Christians shared many of the presuppositions of ancient Judaism. However, Christians often developed these presuppositions in a distinctive way, because 'Jesus and the apostles had an unparalleled redemptive-historical perspective' (Beale 1989:90).

The Scripture is God's word: In 1st-century Palestine the authority of the Hebrew, Greek and Aramaic versions of Scripture was never in doubt (Hays \& Green 1995:223-224; Moyise 2001:16). The presupposition of interpretation was that Scripture was inspired by God and unified, ${ }^{17}$ and as such, is always true and relevant for every circumstance, whether past, present or future (Neusner 2004:2; Longenecker 1975:20; Moyise \& Menken 2004:1; Bock 2006:261). ${ }^{18}$ Thus, New Testament writers could confidently refer to Old Testament passages as 'Scripture' and make authoritative application to the present and to the person and work of Jesus (Moyise \& Menken 2004:1; Kaiser 2007:97-98).

\section{Corporate solidarity}

Corporate solidarity means that a single member of the community could represent the whole and the act of the individual could affect the whole community and vice versa (Bock 2006:261-262; Snodgrass 1994:37). This concept of corporate solidarity is fundamental to any understanding of how the New Testament applies the Old Testament to Jesus (Snodgrass 1994:37; Beale 1989:90, 1999:169)..$^{19}$ On the same principle, promises that applied to Christ and to old Israel were applied directly to the church (Beale 1989:91, 95; Enns 2003:278). ${ }^{20}$

17.The Hebrew Scriptures present the history of Israel as a coherent, sustained narrative of past events, with beginning, middle and end; and with a purpose that explains the present and points to a future goal (cf. Neusner 2004:6)

18.Neusner (2004:2) states, 'Both Judaism and Christianity for most of their histories have read the Hebrew Scriptures in an other-than-historical framework. Whilst, to be sure, they took for granted the historical facticity of Scripture, that was not the main point they sought in Scripture. Rather they found in Scripture's words paradigms of an enduring present, by which all things must take their measure.'

19.For examples of Christ as the new Adam see Romans 5:12-21; 1 Corinthians 15:20-23, 45-49; 2 Corinthians 5:14; 2 Samual 7:12-16; Hebrews 1:5 and 2 $15: 20-23,45-49 ; 2$ Corinthians $5: 14 ; 2$ Samual $7: 12-16$; Hebrews $1: 5$ and 2
Corinthians $6: 18$. For Jesus as the representative of true Israel see for example, Matthew 2:4-22.

20.See for example, 1 Peter 2:4-5; Galatians 3:16, 29; Genesis 12:6; Luke 2:32; Acts 13:47 and 26:23; and Romans 9:24-26. 
Correspondence in history or typology: Correspondence in history or typology is a presupposition that underlies much of Jewish and Christian exegesis of Scripture (Evans 2004:133). ${ }^{21}$ It is the study of biblical history with an eye for correspondences between earlier and later events, persons and institutions, such that significant earlier events, et cetera become the paradigm or pattern for understanding later events, et cetera, which are usually greater in importance, and from a retrospective viewpoint fulfil the earlier pattern. The premise is that God works consistently throughout history according to a sovereign plan and that as ultimate author he has designed Scripture to reveal that historical unity (Hays \& Green 1995:227-228; Bock 2006:262, 271-273; Kaiser 2007:103-105). In fact, typology has been described as 'the basic approach of earliest Christianity toward the Old Testament' (Ellis 1996:53). Thus, patterns from the Old Testament which had already received partial fulfilments were now recognised as fulfilled uniquely and climactically in Jesus (Snodgrass 1994:41; Bock 2006:262). ${ }^{22}$

Eschatological expectation: The early church shared with the Qumran sect the assumption that prophetic passages of Scripture were relevant to their own day, and that contemporary events were the key to understanding those prophetic passages. But there was one major difference. For the early church the last days had already begun with the life, ministry, death and resurrection of Jesus, and with the outpouring of the Spirit and the establishment of the church ${ }^{23}$ (Beale 1989:90; Moyise 2001:11; Bock 2006:263; cf. VanderKam \& Flint 2002:349-350).

Moreover, as opposed to the broad view of Second Temple Judaism, the early church recognised that the arrival of the last days did not mean that the end had come. The last days had been inaugurated with the coming of Jesus, but final salvation for God's people and judgement for their enemies was yet to take place at some later stage in redemptive history (Beale 1989:91; Bock 2006:263). ${ }^{24}$

Messianic expectation: In most of Judaism, it was assumed that the Scriptures were messianic. Many biblical passages that may have been general statements about the nation, prophets, priests, or kings were often idealised in anticipation of God's end-time deliverer who would fill the categories as

21.For further explanations and examples see Beale (2006:21) and Bock (2006: 262-266).

22.See for example: 2 Corinthians 1:10-21; Matthew 5:17, 13:11, 16-17; Luke 24:25-27, 32, 44-45; John 5:39, 20:9 and Romans 10:4. A helpful set of criteria for identifying legitimate types is (1) a type must be connected with historical persons, events, or institutions (Kaiser 2007:104); (2) a type must be found in significant redemptive-historical and theological patterns rather than in minor details (Kaiser 2007:104); (3) a type must be in some way lesser than the anti-type which ultimately fulfils it and (4) a type is usually only recognisable retrospectively in light of the anti-type. For further discussion see Beale (1989:93) and Kaise (2007:103-104).

23.See for example: Matthew 3:2; Mark 1:15; Luke 4:16-20, 21, 7:18-23, 24:43-47; Acts 2:17-21; Romans 15:4; 1 Corinthians 9:10, 10:11; Galatians 4:4; 1 Timothy 4:1; 2 Timothy 3:1; Hebrews 1:1-4, 9:26; 1 Peter 1:12, 20; 2 Peter 3:3; 1 John 2:18. Jude 18 .

24.As a result, some prophecies of Scripture could be cited as only initially or partially fulfilled in Jesus and the early church, and therefore would await and anticipate final, exhaustive fulfilment at the consummation of the age (e.g., Joel in Acts 2:1721). For further examples, see Beale (1994c:269-270). no-one else had (cf. typology). ${ }^{25}$ Thus, the New Testament writers inevitably applied to Jesus biblical passages that had already been recognised as messianic, but because they now knew who the messiah was they could recognise Jesus in even more of the Scriptures (Snodgrass 1994:39-40; Enns 2003:275-276). Thus, recognition of the historical Jesus as the messiah is the distinguishing presupposition and focus of all New Testament use of the Old Testament (cf. McCartney 1988:112-114; Longenecker 1999:190, 208; Enns 2003:275-276; Evans 2004:145).

\section{Methods and goals of Second Temple and New Testament interpretation}

Most if not all of the New Testament writers were Jewish and it is therefore to be expected, and is in fact the case, that they used some common Jewish methods of exegesis (Bock 2006:257; Evans 2004:131; Enns 2003:267-268; Moyise 2001:128). Whilst comparisons should be made with caution, it is helpful to distinguish four main categories of Jewish interpretation: literalist, midrashic, pesher and allegorical (Longenecker 1975:28; cf. Marshall 1994:205).

Literalist interpretation: There are times when Jewish and early Christian exegesis is simply concerned with determining the plain or natural meaning of the text. This type of interpretation is employed throughout the Jewish literature to varying degrees, particularly in the application of Deuteronomic legislation (Longenecker 1975:28-32, 49).

Midrashic interpretation: Midrash is the Hebrew word for interpretation, amplification, exegesis of a holy, revealed text: the written Torah' (Neusner 2004:vii). ${ }^{26}$ The purpose of midrash is 'to update scriptural teaching to make it relevant to new circumstances and issues' (Evans 1992:544, cf. 2004:131-132). ${ }^{27}$ In recent scholarship, the term midrash is used to designate (1) the actual process of exegesis used in Rabbinic hermeneutics; (2) the specific interpretation produced on a particular verse; and (3) the compilation of such interpretations into books (Neusner 2004:vii-viii). ${ }^{28}$ Although much of late Jewish midrash became atomistic, non-contextual and highly imaginative as a form of exegesis (Longenecker 1975:35-38; Evans 1992:545), ${ }^{29}$ it has been viably argued that before AD 70, following the rules developed by Hillel, $^{30}$ Jewish exegetes attempted to interpret Scripture

25.For example, the expectation of an idealised Davidic king: Jeremiah 23:58, 33:15-18; Psalms 89. For further examples from Jewish writings see Kaiser (2007:99).

26.In Rabbinic midrash, Scripture functions as the normative source of enduring truth (facts) on certain themes, of problems to be solved and of proof-texts for certain propositions (Neusner 2004:18-19; cf. vii, 1). By a process of generalisation Scriptural facts are formed into a whole system of theological knowledge, which is a theology (Neusner 2004:208).

27.Compare Helyer (2002:133): The term midrash, broadly speaking, may be used 'to describe the process of contemporising sacred texts.'

28.Ellis (1996:43) describes midrash as both the literary genre and the actual expository methods used to produce it.

29.For the basic types of midrash exegesis see Neusner (2004:15-16, 20-29) and see above on Rabbinic literature.

30.The seven rules of Hillel are Qal wahomer [the light and the heavy], Gezerah shawah [an equivalent regulation], Daber halamed me 'inyano [explanation fromah [an equivalent regulation], Daber halamed me inyano [explanation 'ehad [constructing a family from one passage], Binyan ab mishene kethubim [constructing a family from two texts] and Kayotse bo bemaqom 'aher [constructing a family from two texts] and Kayotse bo bemaqom 'aher Snodgrass 1994:43; Moyise 2001:18 and Bock 2006:260) 
according to its primary, straightforward, contextual meaning (Beale 2006:27-29). ${ }^{31}$ Thus, in the New Testament some examples of early midrash-like interpretations of the Old Testament have been identified by scholars. ${ }^{32}$

Pesher interpretation (Qumran community): Although the Qumran community practised more than one type of interpretation (VanderKam \& Flint 2002:293-302), pesher interpretation was their characteristic technique of scriptural exposition. Unlike midrash, pesher interpretation started with current persons and events and then searched the Scriptures for relevant insight and application (Evans 2004:132; Bock 2006:260). In the Qumran commentaries, the meaning of the passage is adjusted so as to apply directly to the Teacher of Righteousness, the community and their own history and experiences, which are interpreted as nearing the end times (Moyise 2001:9-15; cf. VanderKam \& Flint 2002:293, 303-307). The early church interpreted the Scriptures with similar eschatological fulfilment perspectives, but produced divergent conclusion, because their distinctive, deliberate, all-encompassing hermeneutical focus was upon the person and redemptive work of Jesus Christ (McCartney 1988:107-109, 112-114). ${ }^{33}$

Furthermore, although the meaning of a passage remained a 'mystery' until God revealed its 'solution' to the Teacher of Righteousness (Longenecker 1975:42-43; Marshall 1994:207-209; cf. VanderKam \& Flint 2002:303-307), the Qumran community still recognised the need for a set of rules for exegesis. Significantly for New Testament studies, these rules included the selection of variant readings to promote particular interpretations, deliberate word alterations or substitutions for syntactical and interpretive purposes, thematic stringing together of citations and other methodological parallels. Although disputed, these may legitimately be identified in the New Testament and are characterised as pesher (VanderKam \& Flint 2002:304, 346-361; cf. Marshall 1994:206-209). ${ }^{34}$

Allegorical interpretation (Philo of Alexandria): Philo of Alexandria is considered by most scholars to provide the best source of information on early Jewish allegorical interpretation. ${ }^{35}$ Philo disregarded the historical and literal meaning of the passage and instead sought the deeper, symbolic, 'spiritual' meaning using allegory (Beale 1989:91; Evans 2004:133). The only place in the New Testament where the root word for 'allegory' is found as a verb is in Galatians 4:24 with reference to Sarah, Hagar and the two covenants. Moreover, the use of allegory is very limited in the New Testament (e.g. 1 Cor 9:9; 1 Tim 5:18; 1 Cor 10:1-4), and most

31.See for considerable debate, Beale $(1999,2006 \& 2007)$ opposing the views of Longenecker (1987); Moyise (1999); Enns (2003, 2007).

32.For examples, see Bock (2006:267-268); Moyise (2001:18-19, 131); Evans (1992) and throughout Longenecker (1975). For examples of targumic style see Luke 4:16-20; Isaiah 61:1; Mark 4:12 or Tg Isa 6:10; Luke 6:36 or Tg Ps-J Lev 22:28; Romans 10:6-8 or Tg Neof Deut 30:11-14.

33.See Luke 24:44-47 and 1 Peter 1:10-12. See Ellis (1996:49) and Snodgrass (1994:42) for New Testament examples of eschatological fulfilment exegesis.

34.For examples see Ellis (1996:57); Moyise (2001:130) and Kaiser (2007:97).

35.For a full discussion see Helyer (2002:311-335). scholars recognise typology as characteristic of the New Testament as opposed to allegory (see Marshall 1994:205; Moyise 2001:129; Evans 2004:133; Bock 2006:273).

\section{Conclusion}

In conclusion, comparison with Second Temple interpretive presuppositions, methods and goals does provide helpful insight into the hermeneutical practices of Jesus and the New Testament writers. However, the unique perspective and different goal of Christian exegesis meant that the New Testament writers developed a distinctive hermeneutical approach. They used some of the forms and methods of Jewish exegesis, but not identically, in their entirety or without adjustment, and with different results (Bock 2006:257; Moyise 2001:19; Hays \& Green 1995:231). Thus, parallels in contemporary Jewish sources seldom fully explain the New Testament use of the Old Testament (Hays \& Green 1995:231). For this reason, we do not agree with those who insist that the Second Temple interpretive environment was determinative of how Jesus and the New Testament writers understood the Old Testament (cf. Enns 2003:267-268, 273-275). Comparisons with Second Temple interpretive methods must always be carefully qualified because the interpretive goal is more important than the interpretive method. ${ }^{36}$ Considering that the clear, distinctive, definite and personal focus of the New Testament use of the Old Testament is the sufferings and resurrection of Christ and the proclamation of His redemptive work to all nations (e.g. Lk 24:44, 47; 1 Pt 1:10-12), this same focus must always be the goal of Christian interpretation (McCartney 1988:112-115; Beale 2006:28; cf. Enns 2003:282). ${ }^{37}$

\section{Aspects of present day literary theory}

\section{An appraisal of relevance for studies on New Testament use of the Old Testament}

\section{Intertextuality}

A literary theory favoured by several scholars for application on New Testament use of the Old Testament is that which uses the concept of intertextuality (Hays \& Green 1995:230, 238; Moyise 2000:16-17). At the simplest level of intertextual echo it is argued that the presence of a text ${ }^{38}$ within a text may be barely perceptible and yet, especially if it is frequent and well known, its effect on the reader will be profound (Hays 1989:155; Moyise 2000:14, 17-25). Moreover, a writer may have intended to echo, build upon and interpret an earlier

36 .For example, as a method of interpretation, midrash is not unique to Rabbinic Judaism, but is used wherever different communities give privileged place to certain normative writings. However, using the same methods they arrive at unique interpretations because of their different presupposed theologies (cf. Neusner 2004:viii-ix).

37.Jesus and the New Testament writers have the right interpretive goal (McCartney 1988:110). 'Jesus himself was the originator of the main interpretive approaches and presuppositions employed by his followers, especially the christocentric focus on the Old Testament; ... Can we be bold enough in a scholarly forum to ask the question whether or not Jesus' interpretive perspective was wrong?' (Beale
1999:172).

38.In order to be consistent with the terminology of literary theory, text is used in this section where elsewhere we have used 'passage' to refer to a portion of Scripture and text to refer to whole documents. 
textual pattern, or he or she may have been unconscious of the echo now perceived by the reader (Hays \& Green 1995:228-229).

At another level, intertextuality may be described as dialogical, where text and subtext 'coexist in creative tension' (Moyise 2000:30), mutually and simultaneously affecting and interpreting one another. Considering that the author juxtaposes old texts within a new context without full explanation, the intended meaning becomes dynamic and an outstanding ambiguity remains. However, the potential meaning of the text is still limited by the aim of determining the author's intention (Moyise 1999:54-57, 2000:17, 25-26). ${ }^{39}$

The final, most extreme level of postmodern intertextuality proposes that the introduction of a new text into a complex matrix of intertexts disturbs and influences the meaning of the whole literary complex and its interpretive network (Hays \& Green 1995:228; Moyise 1999:55-56; Moyise 2001:136). As a result, meaning is always unstable and is located between texts rather than within texts (Vanhoozer 1998:135). Every text possesses an indeterminate surplus of potential meaning dependent upon how these multiple textual interactions are configured by the reader (Moyise 2000:33, 37). ${ }^{40}$ Thus, postmodern intertextuality becomes inseparable from reader-response theory (see below) ${ }^{41}$

However, other scholars are very wary of the intertextual approach arguing convincingly that the concept of never ending interconnectedness and open-ended meaning undermines the possibility of determining any definite meaning of texts (Thiselton 1992:506; Vanhoozer 1998:122-123, 135; Beale 1999:157-158, 164, 178; cf. Moyise 2001:136-137).

In our view, the first two categories of intertextual echo and dialogical interaction are the most helpful. The best approach is to qualify and limit the implications of intertextuality for New Testament use of the Old Testament by insisting that whilst the old and new texts mutually interpret one another, there is no ultimate ambiguity about the original author's intended, singular meaning. Likewise, the original meaning of the old text is not ultimately distorted, but only creatively developed in the new text (Beale 2006:40).

\section{Reader-response theory}

Reader-response critics argue that meaning is inherently unstable, multiple and dependent upon the reader who always brings other texts to a text so that a text may never be read in isolation from other texts (Moyise 2000:1518). Considering that a text does not simply produce its 39.For further examples see Moyise (2000:27-32).

40.Enns (2003:285) says as much when he states, 'Christian, apostolic proclamation of the OT is a subtle interpenetration of a myriad of factors, both known and unknown, that can rightly be described not as a product of science but as a work of art.'

41.For further explanation and application see especially Moyise (2000:33-40). See also Moyise (2008) and Moyise and Van Rensburg (2002). meaning independently of the reader, readers inevitably become involved, consciously or unconsciously, in constructing meaning as soon as they try to make sense of textual interactions (Moyise 1999:54, 57-58; cf. Beale 1999:163-164). Valid meaning is not set by the author and singular, but produced or reproduced by the reader and multiple, depending on the socio-historic, religious and ethical presuppositions of the reader (Moyise 2000:33, 37-38; cf. Beale 1999:162). The logical implication is that it is impossible to be certain (or unnecessary to decide) who is correct (Moyise 1999:57-58) because no text could ever be misunderstood (Beale 1999:172).

It is important to be aware that all readers, whether 1st-century or 21st century, come to a text with preconceived worldviews which determine their questions, the answers they expect, and the way they get answers out of the text. As a consequence, present day Christian interpreters must recognise that their own worldviews and hermeneutical grids are inevitably a mixture of biblical and unbiblical perspectives and presuppositions. Thus, they need to strive continually to counteract unbiblical views of reality and replace them with biblical ones (McCartney 1988:104-105; Beale 2006:31). It is important to observe that the New Testament writers are inspired authors whose presuppositions (as far as they impact on their writings) are correct and authoritative, completing for the Christian a legitimate biblical worldview (cf. Beale 1999:167-170).

Our objection to reader-response theory is, firstly, that the aim of teasing out every potential meaning of a text is more likely to reveal what the text does not mean, whilst the whole purpose of the hermeneutics of the Reformation is to arrive at the most probable, intended meaning of the text (cf. Beale 1999:164; cf. Moyise 2000:39-40). The most probable meaning of the text as intended by the author is the one that logically makes the most coherent and natural sense of the biblical data (Beale 1999:165-166, 175). Although no individual may perfectly grasp the original intended meaning of a text, it is reasonable to assume that a reader may still attain a valid understanding which adequately overlaps with the intended meaning of the original author (Beale 1999:152-163, 177; cf. Moyise 2000:37-38; Vanhoozer 1998:209, 218 \& 255). ${ }^{42}$

Secondly, the ideologies that compel sincere scholars to find divergent meanings are not all equally valid in the light of the overall message of the Bible (cf. Beale 2006:31). The presupposition in the case of Scriptural interpretation is that God is the ultimate author of every individual biblical passage as well as the whole canon, and $\mathrm{He}$ intends and is able to communicate to finite creatures a reasonably certain knowledge of what He means (cf. McCartney 1988:106-107; cf. Moyise 2000:40; cf. Beale 1999:164-165, 178-179). ${ }^{43}$ Finally, because the New Testament authors were inspired by the Holy Spirit to complete the revelation of Jesus Christ (see e.g. Jn 16:13-14), it follows that subsequent

42.Thus, I disagree with Enns (2003:283) who states, 'what if biblical interpretation is not guided so much by method but by an intuitive, Spirit-led engagement of Scripture with the anchor being not what the author intended but by how Christ gives the OT its final coherence?'

43.See below on Sensus plenior. 
readers are dependent on the illumination of the Holy Spirit for correct understanding. This means that reading the Bible is a spiritual exercise and not merely an intellectual one.

\section{Further hermeneutical issues in studies on New Testament use of the Old Testament}

The New Testament use of the Old Testament is mostly not explainable only in terms of a grammatical-historical exegesis. Thus, several hermeneutical issues often arise and need discussion.

\section{Sensus plenior and author's intention}

New Testament writers often appear to understand and apply Old Testament passages in ways that go beyond the original human authors' intended meanings. Sensus plenior is a Latin term used by scholars to refer to the 'fuller sense' God intended for a passage (Snodgrass 1994:34). ${ }^{44}$

There are two clearly distinct evangelical views on sensus plenior (cf. Bock 2006:269; Marshall 1994:213; Beale 1989:91-92):

- The first position is that the full, single meaning of Old Testament passages is exactly what the original human authors intended and were fully aware of. The New Testament writers only applied the one meaning to new situations (McCartney 1988:102; Beale 1989:96, n. 43; Moyise 2001:133; cf. Kaiser 2007:94, 101-103). The problem with this view is that grammatical-historical exegesis alone does not account for how the New Testament writers actually interpret Scripture (McCartney 1988:102-103; Enns 2003:266-269).

- The best understanding of sensus plenior depends on the presupposition that God is sovereign over history and author of all Scripture and that later biblical revelation is the broad context for understanding earlier biblical revelation (Marshall 1994:212). Thus, with the death and resurrection of Jesus as the key to understanding, and under the inspiration of the divine author, the New Testament writers could recognise and draw out new implications and applications of what the Old Testament authors wrote. This means that the Old Testament authors did not necessarily understand the full significance of what they wrote. Thus, the fuller sense intended by God became apparent from a retrospective point of view, but was never disconnected from the meaning intended by the original human author (Beale 1989:90-93, 1999:164-165; Bock 2006:264, 268-269; cf. Enns 2003:269). ${ }^{45}$

\section{The problem of attention to the Old Testament context}

The issue of whether or not the New Testament writers show respect for the original Old Testament contextual meaning 44.See Moo (1986) and Poythress (1986) for a full treatment of this issue.

45.For Scripture references used in support of this view see John 11:49-52; Galatians 3:16; 1 Peter 1:10-12 and Danial 12:5-13. For examples of fuller sense see Bock (2006:268-269). of the passages they cite is still one of the most frequently debated amongst scholars (Marshall 1994:196, 202; Moyise 2000:17). ${ }^{46}$

One perspective is that although New Testament writers were always aware of Old Testament contexts, they did not always respect Old Testament contexts. As a result, they often creatively used the Old Testament without regard for its original contextual meaning and even contradicted its intended meaning. In particular, it is implied that when New Testament authors somehow modify the meaning of the passage, they are disrespecting the Old Testament context (Moyise 1999:56-57, 2001:134; cf. Beale 1994b:7, 9). ${ }^{47}$

However, in our view, other scholars argue convincingly that although the New Testament writers use the Old Testament creatively, their biblical presuppositions ensure that their dominant approach is to show respect for the intended meaning of the passage in its original context (Beale 1999:152, 2006:23-24). ${ }^{48}$ Respect for Old Testament context implies conformity in the sense of significant likeness or relatedness, but not absolute replication (cf. Beale 1999:168). Possible examples of intentional non-contextual use are highly exceptional ${ }^{49}$ considering the overall number of times that the New Testament refers to Old Testament passages (Beale 2006:27, cf. Enns 2005:116). In fact, these examples may not be beyond viable explanation either in terms of grammatical-historical exegesis or in terms of biblicaltheological and typological approaches which are not purely grammatical-historical, but are neither non-contextual (Beale 2006:20-23; cf. Enns 2005:159; Kaiser 2007:103-104). ${ }^{50}$ Of course, when allusions to Old Testament passages are most likely unintentional, non-contextual use is to be expected (Beale 1989:90; Bock 2006:270-271).

\section{Normativity of New Testament exegetical methods}

Are present day interpreters compelled to imitate all the exegetical methods used by Jesus and the New Testament writers? Or were some of their methods illegitimate by present day standards and yet somehow uniquely validated by the 46.See also Beale (1989) and Moyise (1994).

47.For examples see Beale (1994a) Enns (2003, 2005:115, 160).

48.For examples see Beale (1994a), the contributors to Beale and Carson (2007) and Enns (2003:269).

49.These include: 1 . Ad hominem argumentation: the role of angels revealing the law in Galatians 3:19; the Exodus 'veil' theme in 2 Corinthians 3:13-18; 2. Non-contextual Galatians $3: 19$; the Exodus 'veil' theme in 2 Corinthians $3: 13-18$; 2 . Non-contextual
midrashic treatments: the understanding of baptism and the 'following rock' in 1 midrashic treatments: the understanding of baptism and the 'following rock' in 1
Corinthians 10:1-4; Deuteronomy 30:12-14 in Romans 10:6-8; Abraham's seed in Galatians 3:16 and 29; Psalms 68:18 in Ephesians 4:8; 3. Allegorical interpretations: Deuteronomy 25:4 in 1 Corinthians 9:9; the Old Testament in Galatians 4:24; Genesis 14 in Hebrews 7; 4. Atomistic interpretation: Isaiah 40:6-8 in 1 Peter 1:24ff. (Beale 1989:90); Exodus 3:6 in Luke 20:27-40; Hosea 11:1 in Matthew 2:15; Isaiah 49:8 in 2 Corinthians 6:2; Isaiah 59:20 in Romans 11:26-27; Psalms 95:9-10 in Hebrews 3:7-11 (Enns 2005:114-142).

50.See above on the presupposition of correspondence in history and typology and on sensus plenior. Typological approach: 'The later use grows out of the earlier narrated event and, thus, is organically or contextually related to it and its meaning; whilst being a progressive revelatory development of the Old Testament text, it whilst being a progressive revelatory development of the Old Testament text, it
is not inconsistent with the original context' (Beale 2006:21). Biblical theological approach: The interpretation of texts in the light of their broader literary context and their broader redemptive-historical epoch in order to explain earlier texts in the light of the progress of revelation without ultimately distorting their original contextual meaning (Beale 2006:40). 
inspiration of the Holy Spirit? (Beale 1994b:8; Longenecker 1987:8; Snodgrass 1994:49).

One conclusion is that New Testament writers characteristically use the Old Testament in non-contextual ways, and therefore present day interpreters should not attempt to imitate inspired apostolic exegesis. However, most evangelical interpreters argue that if the authority of the New Testament interpretations is not to be denied and if the underlying presuppositions of the New Testament writers are kept in mind, the exegetical methods of the New Testament writers should also be viewed as normative for all subsequent exegesis of the Old Testament (Beale 1989:90-94; Enns 2005:115-116; Longenecker 1987:38; cf. Enns 2003:280-282).

Another view is that the characteristically non-contextual methods of the New Testament writers should be viewed as a hermeneutical trajectory to be embraced (Enns 2003:265-267, 281-282). Thus, it is advocated that present day interpreters should not impose present day grammatical-historical exegesis as normative (Enns 2003:283, cf. 2005:159). ${ }^{51}$ Instead they should accept that apostolic hermeneutics is only explainable in terms of Second Temple non-contextual interpretive methods and traditions (Enns 2003:265, 2005:130-131). ${ }^{52}$ The problem with this view is its unproven assumption that Second Temple hermeneutical methods were characteristically non-contextual and determinative of New Testament practice (Enns 2003:269-273; cf. Beale 2006:26-27). ${ }^{53}$

The most convincing view is that although Jesus and the New Testament writers go beyond what may be established using grammatical-historical principles alone (Enns 2003:266-269), ${ }^{54}$ present day interpreters should view the grammatical-historical method as the normative starting point of exegesis. They should then go on to imitate the New Testament Christological focus and consideration of the broader typological and biblical-theological (redemptivehistorical) context (McCartney 1988:114).

\section{The distinction between meaning and significance}

Often scholars ${ }^{55}$ deal with 'odd' uses of the Old Testament by the apostles by distinguishing between meaning and significance. The presupposition of Second Temple and Christian interpretation was that Scripture is always relevant to the contemporary situation. Therefore, the aim was not 51.See also Enns $(2003: 263-265,279)$ and Enns (2007).

52.Enns actually contends that many times Jesus and the New Testament writers approach the Old Testament 'in ways that are adverse to grammatical-historical exegesis but firmly at home in the Second Temple world' (Enns 2003:269-270). He also argues that Jewish traditions reflected in the New Testament are fictitious and yet are passed on as historical. However, one cannot be sure that the few traditions reflected in the New Testament are not historical.

53.To identify Christ and the apostles as first-century Jews does not mean that their hermeneutics were defined, determined or limited by mere or stereotypical 1st-century Jewish hermeneutics.

54.See above on the problem of attention to Old Testament context

55.For recent discussion of this subject see Vanhoozer (1998); Moyise (1999); Beale (1999) and Enns (2003). merely to discover what the passage meant originally (author's intent), but to show its relevance to the new situation (extended meaning and new application). ${ }^{56}$ As a result, Second Temple and Christian interpreters did not always maintain explicitly the distinction between original meaning and new significance (Enns 2003:274-275). Nevertheless, in our view, maintaining the distinction between original meaning and new significance is valid and important (Beale 1999:152; cf. Enns 2005:115-116). Although an Old Testament passage must now be understood in relation to the new context in the New Testament setting, its placement there does not eliminate its original meaning and replace it with an entirely new meaning. Only the passage's significance changes in the light of the coming of Christ (Beale 1999:157-159; cf. Moyise 1999:55-56). Original meaning must not be confused with or collapsed into the extension of that meaning or the application of that meaning to new contexts (Beale 1999:155-159; cf. Vanhoozer 1998:260).

\section{Conclusions}

Firstly, it is recognised that the study of New Testament use of the Old Testament is extremely complex and continues to involve interpreters in significant historical, linguistic and hermeneutical challenges (Moyise 2001:137; Bock 2006:275-276). However, the findings of this survey of current scholarship may be summarised as follows. Although the Old Testament text and canon were not yet fixed during the first century AD, the New Testament writers often argued from the Scriptures as their basis of authority. They made wide use of the many different versions of the Old Testament available to them, depending on their particular purposes. Thus, it is important to be aware of the various sources of Scripture available to Jesus and the New Testament writers. In addition, at times the New Testament writers may have used testimonia, relied on memory or altered the text form for semantic or interpretive purposes.

Secondly, whilst early Christians shared some of the interpretive assumptions and practices of Second Temple Judaism, their exegesis of the Old Testament emerged as distinctive. As a result, it is important to understand both the shared Jewish and distinctively Christian presuppositions that underlie the exegetical methods used by the New Testament writers. In particular, the influence of Jesus' own teaching and redemptive work should be considered before the influence of any Second Temple texts and methods. Considering that the New Testament writers are inspired authors, their presuppositions (as far as they impact on their writings) are valid and authoritative, completing for the Christian a legitimate biblical worldview.

Thirdly, the exegetical methods of the New Testament writers should be viewed as normative, providing a model for present day exegesis of the Old Testament. The biblical evidence shows that the dominant approach of the New Testament authors was to respect the Old Testament context 56.Extended meaning refers to any ongoing implications intended by the original author whilst new application refers to the creative application of the original meaning to the new context (Beale 1999:157). 
and therefore use the Old Testament in a manner consistent with the original Old Testament author's intention. Significantly, the New Testament authors frequently used a typological approach in working out fulfilment in Christ within the broad context of redemptive history. As a consequence, the grammatical-historical method should be used as the foundation of present day interpretation, but always in conjunction with other interpretive methods such as the biblical-theological and typological approaches. However, because the interpretive goal influences interpretive conclusions more than interpretive methods, it is more important to imitate the apostolic interpretive goal than their interpretive methods. The clear, definite and distinctive goal of New Testament use of the Old Testament is Christ and his redemptive work.

Fourthly, it is important to be aware that all interpreters, ancient and present day, are influenced by worldviews and not only by the Bible. Therefore, present day interpreters must continually seek to make their own worldviews and methods more compatible (although not identical) with the biblical worldview as authoritatively completed by the New Testament writers. The validity of present day interpretations should be evaluated upon how well they argue for the meaning intended by the biblical author and make sense of the majority of the biblical data. Essentially, the presupposition is that God, as ultimate author of Scripture, is able to communicate a reasonably certain knowledge of his intended meaning.

Fifthly, intertextuality is helpful for understanding New Testament use of the Old Testament provided that the dynamic relationship between texts is not said to obliterate or distort the original intended meaning of the Old Testament passage. The reader-response strategy is often unhelpful because it usually ignores consideration of the most probable, intended meaning of the passage and advocates pursuing every potential meaning for the New Testament passage determined by the reader in every new context. However, it is reasonable to assume that a reader can and should seek an understanding which adequately overlaps with the intended meaning of the original author.

Finally, it is important to distinguish between meaning, anchored by the author's intention, and new significance, defined in terms of extended meaning and new application. Thus, the original meaning of the Old Testament passage is not changed by its being placed into a New Testament context, but it does gain new significance in the light of the coming of Christ. The presupposition is that under inspiration, the New Testament writers could expand the meaning and draw out new applications of the Old Testament not fully understood or intended by the original authors.

In light of the above conclusions, the following methodological procedure is proposed as the most effective, integrated and Reformed evangelical approach to interpreting New Testament use of the Old Testament:
- Identify the Old Testament passages in the New Testament passage (cf. Hays \& Green 1995:232; Snodgrass 1994:48).

- Analyse the Old Testament reference within its own Old Testament context (literary and historical) to determine its most likely meaning as intended by the original author (cf. Hays \& Green 1995:232; Bock 2006:274).

- Examine the textual background of the Old Testament reference and compare this with the text form in the specific New Testament context. ${ }^{57}$ Identify any apparent modifications by the New Testament author and consider possible reasons for modifications (Hays \& Green 1995:232; Bock 2006:275).

- Analyse the Old Testament reference within the specific context in the New Testament (i.e. literary and sociohistoric context) to determine its function within the argument or narrative of the author (cf. Hays \& Green 1995:232; Bock 2006:275). ${ }^{58}$ Also, consider the New Testament writer's recognition of the specific and wider contexts of the Old Testament passage (cf. Marshall 1994:202; Hays \& Green 1995:232). Finally, compare the particular New Testament writer's pattern of use of the Old Testament passage with that by other New Testament authors (cf. Snodgrass 1994:45).

- Examine how the Old Testament reference was understood and used in later Scripture itself and in ancient Jewish writings. Then compare this with its use in the specific New Testament context (cf. Snodgrass 1994:40, 48) in order to assess whether or not the New Testament writer reflects or challenges traditional interpretations (cf. Hays \& Green 1995:232; Evans 2004:134; Bock 2006:275)..$^{59}$

- Determine the theological presuppositions that are relevant to the particular use of an Old Testament passage, such as corporate solidarity, correspondence in history, eschatological fulfilment, messianic expectation and the church as the true Israel (cf. Snodgrass 1994:48; Hays \& Green 1995:232).

- Determine the type of usage the New Testament writer is making of the Old Testament and consider whether the New Testament writer's use of the Old Testament may parallel any specific midrash-like or pesher-like techniques (cf. Snodgrass 1994:48; Bock 2006:275).

- Consider whether or not any dynamic intertextual resonance has been created by the author such that reference to one Old Testament passage is likely to have brought to the mind of the reader a number of other related passages. ${ }^{60}$

- Finally, integrate all one's analyses and summarise the exegetical and theological significance and relevance of the particular New Testament use of the Old Testament passage(s) (cf. Snodgrass 1994:48).

57.Note any variations already in the Masoretic Text or Septuagint traditions.

58. Note whether or not an introductory formula is used.

59.Be careful to check the dating of all ancient Jewish sources as many may in fact post-date the New Testament era whilst still shedding some helpful interpretive insight (cf. Bock 2006:274).

60.The intertextual significance created by the New Testament reference to the Old Testament passage must remain coherent with the originally intended meaning of the Old Testament passage. 
Thus, it is proposed that the implementation of this procedure will more consistently enable interpreters to obtain valid results that effectively explain the meaning intended by the biblical authors and make sense of the majority of the biblical data.

\section{Acknowledgements Competing interests}

The authors declare that they have no financial or personal relationship(s) which may have inappropriately influenced them in writing this article

\section{Authors' contributions}

G.Y.P. (North-West University) was responsible for the research and writing of this manuscript as part of his PhD programme. F.J.v.R. (North-West University) gave comment and suggestions on the manuscript as $\mathrm{PhD}$ promoter from the New Testament perspective. H.F.v.R. (North-West University) gave comment and suggestions on the manuscript as $\mathrm{PhD}$ co-promoter from the Old Testament perspective.

\section{References}

Beale, G.K., 1989, 'Did Jesus and his followers preach the right doctrine from the wrong texts? An examination of the presuppositions of Jesus' and the apostles' exegetical method', Themelios 14(3), 89-96.

Beale, G.K. (ed.), 1994a, The right doctrine from the wrong texts? Essays on the use of the Old Testament in the New, Baker, Grand Rapids, MI.

Beale, G.K., 1994b, 'Introduction', in G.K. Beale (ed.), The right doctrine from the wrong texts? Essays on the use of the Old Testament in the New, pp. 7-10, Baker, Grand Rapids, MI.

Beale, G.K., 1994c, 'The use of the Old Testament in Revelation', in G.K. Beale (ed.) The right doctrine from the wrong texts? Essays on the use of the Old Testament in the New, pp. 57-276, Baker, Grand Rapids, MI.
the

Beale, G.K., 1999, 'Questions of authorial intent, epistemology, and presuppositions and their bearing on the study of the Old Testament in the New: A rejoinder to Steve Moyise', Irish Biblical Studies 21(November), 151-180.

Beale, G.K. 2006, 'Did Jesus and the apostles preach the right doctrine from the wrong texts? Revisiting the debate seventeen years later in the light of Peter Enns' book, Inspiration and incarnation', Themelios 32(1), 18-43.

Beale, G.K., 2007, 'A surrejoinder to Peter Enns', Themelios 32(3), 14-25.

Beale, G.K. \& Carson, D.A. (eds.), 2007, Commentary on the New Testament use of the Old Testament, Baker Academic \& Nottingham: Apollos, Grand Rapids, MI.

Bock, D.L., 2006, 'Scripture citing Scripture: Use of the Old Testament in the New', in D.L. Bock \& B.M. Fanning (eds.), Interpreting the New Testament text: Introduction to the art and science of exegesis, pp. 255-276, Crossway, Wheaton, IL.

Collins, J.J. \& Evans, C.A. (eds.), 2006, Christian beginnings and the Dead Sea Scrolls, Baker Academic, Grand Rapids, Ml.

Dodd, C.H., 1952, According to the Scriptures: The substructure of New Testament Theology, Nisbet, London.

Ellis, E.E., 1993, Prophecy and hermeneutic in early Christianity, Baker, Grand Rapids, MI.

Ellis, E.E., 1996, 'The New Testament's use of the Old Testament', in B. Corley, S.W. Lemke \& G. Lovejoy (eds.), Biblical hermeneutics: A comprehensive introduction to interpreting Scripture, pp. 40-58, Broadman \& Holman Publishers, Nashville, TN.

Enns, P., 2003, 'Apostolic hermeneutics and an Evangelical doctrine of Scripture: Moving beyond a modernist impasse', Westminster Theological Journal 65, 263-287.

Enns, P., 2005, Inspiration and incarnation: Evangelicals and the problem of the Old Testament, Baker, Grand Rapids, MI.

Enns, P., 2007, 'Response to Professor Greg Beale', Themelios 32(3), 5-13.

Evans, C.A., 1992, 'Midrash', in J.B. Green, S. McKnight \& I.H. Marshall (eds.), Dictionary of Jesus and the Gospels, pp. 544-548, IVP, Downers Grove, IL.
Evans, C.A., 2004, 'The Old Testament in the New', in S. McKnight \& G.R. Osborne (eds.), The face of New Testament studies: A survey of recent research, pp. 130-145, Baker Academic, Grand Rapids, MI.

Fitzmyer, J.A., 2000, The Dead Sea Scrolls and Christian origins: Studies in the Dead Sea Scrolls and related literature, Eerdmans, Grand Rapids, MI/Cambridge.

Grudem, W., 1994, Systematic theology: An introduction to biblical doctrine, IVP, Leicester/ Zondervan, Grand Rapids, MI.

Hays, R.B., 1989, Echoes of Scripture in the letters of Paul, Yale University Press, New Haven.

Hays, R.B. \& Green, J.B., 1995, 'The use of the Old Testament by New Testament writers' in J.B. Green (ed.), Hearing the New Testament: Strategies for interpretation, pp. 222-238, Eerdmans, Grand Rapids, MI.

Helyer, L.R., 2002, Exploring Jewish literature of the Second Temple period: A guide for New Testament students, IVP, Downers Grove, IL.

Herbert, E.D. \& Tov, E. (eds.), 2002, The Bible as book: The Hebrew Bible and the Judaean desert discoveries, The British Library, London.

Kaiser, W.C. Jr., 2007, 'Does the New Testament accurately use the Old Testament?' in W.C. Jr. Kaiser \& M. Silva (eds.), Introduction to biblical hermeneutics: The search for meaning, revised and expanded edn., pp. 95-106, Zondervan, Grand Rapids, MI.

Lindars, B., 1976-1977, 'The place of the Old Testament in the formation of New Testament theology: Prolegomena', New Testament Studies 23, 59-66.

Longenecker, R., 1975, Biblical exegesis in the apostolic period, Eerdmans, Grand Rapids, MI.

Longenecker, R.N., 1987, "'Who is the prophet talking about?" Some reflections on the New Testament's use of the Old', Themelios 13(1), 4-8.

Longenecker, R., 1999, Biblical exegesis in the apostolic period, 2nd edn., Eerdmans, Grand Rapids, MI.

Marcos, N.F., 2006, 'Rewritten Bible or imitation? The vestments of the high-priest', in P.W. Flint, E. Tov \& J.C. VanderKam (eds.), Studies in the Hebrew Bible, Qumran, and the Septuagint presented to Eugene Ulrich. Supplements to Vetus Testamentum, vol. 101, pp. 321-336, Brill, Leiden.

Marshall, I.H., 1994, 'Counter response in favour of C.H. Dodd's view: An assessment of recent developments' in G.K. Beale (ed.), The right doctrine from the wrong texts? Essays on the use of the Old Testament in the New, pp. 195-216, Baker, Grand Rapids, MI.

McCartney, D.G., 1988, 'The New Testament's Use of the Old Testament', in H.M. Conn (ed.), Inerrancy and hermeneutic: A tradition, a challenge, a debate, pp 101-116, Baker Book House Grand Rapids, Michigan.

Mickelsen, A.B., 1963, Interpreting the Bible: A book of basic principles for understanding the Scriptures, Eerdmans, Grand Rapids, MI.

Moo, D., 1986, 'The problem of sensus plenior', in D.A. Carson \& J.D. Woodbridge (eds.), Hermeneutics, authority and canon, pp. 179-211, Zondervan, Grand Rapids, MI.

Moyise, S., 1994, 'Does the New Testament quote the Old Testament out of context?', Anvil 11, 133-143.

Moyise, S., 1999, 'The Old Testament in the New: A reply to Greg Beale', Irish Biblical Studies 21, 54-58.

Moyise, S. 2000, 'Intertextuality and the study of the Old Testament in the New Testament', in S. Moyise (ed.), The Old Testament in the New Testament: Essays in honour of J.L. North, pp. 14-41, Sheffield Academic Press Sheffield.

Moyise, S., 2001, The Old Testament in the New: An introduction, Continuum, London.

Moyise, S. (ed.), 2008, Evoking scripture: Seeing the Old Testament in the New, T \& T Clark London.

Moyise, S. \& Menken, M.J.J., 2004, The Psalms in the New Testament, T \& T Clark, London and New York.

Moyise, S. \& Van Rensburg, F.J., 2002, 'Isaiah in 1 Peter 3:13-17: Applying intertextuality to the study of the OT in the NT,' Scriptura 80, 275-286.

Neusner, J., 2004, Judaism and the interpretation of Scripture: Introduction to the Rabbinic Midrash, Hendrickson, Peabody, MA.

Poythress, V.S., 1986, 'Divine meaning of Scripture', Westminster Theological Journa 48, 241-279.

Schiffman, L., Tov, E. \& VanderKam, J.C. (eds.), 2000, The Dead Sea Scrolls fifty years after their discovery 1947-1997, Israel Exploration Society, Jerusalem.

Snodgrass, K., 1994, 'The use of the Old Testament in the New', in G.K. Beale (ed.), The right doctrine from the wrong texts? Essays on the use of the Old Testament in the New, pp. 29-51, Baker, Grand Rapids, MI.

Thiselton, A.C., 1992, New horizons in hermeneutics, HarperCollins, London.

Tov, E., 2001, Textual criticism of the Hebrew Bible, 2nd rev. edn., Fortress, Assen, Maastricht/Van Gorcum, Minneapolis.

VanderKam, J.C., 2001, An introduction to early Judaism, Eerdmans, Grand Rapids, MI.

VanderKam, J.C. \& Flint, P., 2002, The meaning of the Dead Sea Scrolls: their significance for understanding the Bible, Judaism, Jesus, and Christianity, Harper, SanFrancisco, New York.

Vanhoozer, K.J., 1998, Is there meaning in this text, Zondervan, Grand Rapids, MI. 